\title{
AUTOMATED DECISION MAKING IN ADMINISTRATIVE PROCEDURE - MYTH OR REALITY?
}

\author{
Zoran Jovanović ${ }^{1}$, Stefan Andonović \\ University of Kragujevac, Faculty of Law, Serbia
}

\begin{abstract}
In this paper the authors analyse the possibility of automated decision making in the administrative procedure, as one of the aspects of e-administration development. Services of e-administration are developing and expanding to numerous aspects of administrative work, with administrative decision making being one of the most important and intriguing aspect. Having that in mind, the authors defined the term automated decision making and researched the question whether the legal framework of the Republic of Serbia enables the implementation of new, digital forms of administrative decision making. For that purpose, relevant provisions of the Law on General Administrative Procedure, the Law on Electronic Government and the Law on Personal Data Protection have been analysed. The authors identified the situations of general administrative procedure within which it would be possible to consider practically, and in the near future normatively as well, the introduction of an automated decision making in the administrative procedure. A lesser portion of the paper is dedicated to the prerequisites and risks related to human rights and liberties when it comes to automated decision making in the administrative procedure.
\end{abstract}

Keywords: e-administration, administrative procedure, administrative decision making, automated decision making.

\section{INTRODUCTORY CONSIDERATIONS}

The Internet and the information and Nowadays, people around the world use communications technologies repre- smart computers, mobile phones, tablets sent the basic characteristics of modern and other information devices in order society that operates on its possibilities to record a text, hold a meeting, park and high reach (Petrović, 2014: 16-19). their car, but also to calculate the prob-

1 Corresponding author: zjovanovic23@gmail.com. 
ability of precipitation, changes in the national exchange rate, to conduct digital surveillance of their business facilities and many other things. Information and communication technologies have therefore influenced almost every area of social life, changing the traditional patterns of behaviour, customer service, means of communication, product creation, etc.

Over time, new technologies have influenced the way the countries and the state authorities operate. State authorities around the world are being modernized and improved, accepting trends of using IT devices and digital business within their activities. In that way, the speed of conducting business, the efficiency and the scope of work that these bodies can perform has increased (Jovanović, 2018: 34).

All the innovations mentioned are also conducted as part of the process of digitalization of work of public authorities, which influences the very nature of today's public administration (Dimitrijević, 2009: 125). Thanks to these changes and development, e-government is becoming one of the key instruments in achieving sustainable development in different areas of social life (Jovanović, 2016: 684).

E-government can be applied through a number of institutes. One of the most interesting institutes in relation to new technologies and e-government that appears is related to the possibility of automated decision making in the administrative procedure (Coglianese \& Lehr, 2017: 1147-1223). Considering the legal regulation, the advance of technology and the risks to civil rights and liberties, the authors of this paper pose a question whether there is a factual, but also a legal possibility that decisions in the admin- istrative procedure in the Republic of Serbia are made solely by the use of information systems (computer programs) by inputting necessary information and data. Administrative decision making by information systems would enable more efficient work and faster performance of administrative bodies, the reduction of administrative procedure costs and better application of public and private interests. However, in addition, such a way of decision making would create risks to privacy, personal data and other rights of citizens.

Therefore, the main subject of this paper concerns the de lege lata and de lege ferenda analysis of the possibility of an automated (information systems) decision making in the administrative procedure. The primary goal of the authors is to deepen the fund and the level of scientific research concerning new technologies and administrative procedure and therefore indicate the theoretical and practical possibilities of applying autonomous IT systems in the process of administrative decision making.

The analysis of the posed questions and the achievement of the goals of the paper require its specific structure as well. Namely, we begin the analysis by reviewing the very concept of automated decision making and the classification of administrative activities suitable to be automated. Thereafter, the research includes a legal analysis of the possibilities of automated decision making within the general administrative procedure in the Republic of Serbia. At the end, the authors express their views on the question of the prerequisites and obstacles to the implementation of automated decision making in administrative procedure. 


\section{AUTOMATED DECISION MAKING}

In order to successfully examine the main subject of this paper, we must look back at certain concepts of automated decision making. Automated decision making is the process of digital (electronic) analysis of information inputs and making certain conclusions or decisions based on previously set parameters in a specific computer program (software). In this process, the computer program makes a certain type of a decision. In this way, the efficiency of the decision making is influenced, and therefore, the speed of work as well. This type of decision making is mostly used in business analytics, where from the technical side there are more systems of automated decision making (Bhosale, Salunkhe, \& Burondkar, 2020)

The reasons for transferring different tasks from humans to computers are multiple. Nowadays, computer programs are capable of analysing a high volume of facts and information much faster than humans, even groups of people, and offering objective results that are in most cases precise and accurate (in relation to the set parameters). They automatically come to the forecasting of results and therefore represent an exceptionally useful tool in making various choices, restoration of economic losses and in the process of making decision for everyday things (Andonović, 2019: 201). Automated decision making helps in the selection of the shortest route to a destination, notifications regarding the changes in the stock exchange, the selection of the best offer on the market and similar. As stated, "the context of modern decision making sets high demands on decision makers. Among other things, decisions are made more and more under the pressure of conflict of interest for the allocation of resources, resources are often insufficient in time and space or unfavourably distributed (available)" (Srđević, Srđević, \& Suvočarev, 2007: 55). Those decision-making processes have already been implemented in the business practice of numerous companies. Examples of their application include online decision making regarding the possibility of obtaining a loan or credit from a bank or another business entity, or decisions made based on the aptitude tests used for recruitment and hiring which are based on previously programmed algorithms and criteria (UK's independent authority, 2019).

And while the need to reduce costs by accelerating the production and business process is the key characteristic of modern business entities (private sector), the situation in the administrative procedures is somewhat different, since public and private interests are represented.

Namely, in a small number of cases, the countries decide on the application of information technologies that would help or conduct the decision making (Welch, Hinnant, \& Moon, 2004: 372). The literature states that modern examples include "the use of passport scanners at airports to decide whether a person is entitled to enter into the country, the automatic processing of tax refunds and Australia's controversial welfare debt recovery system - colloquially known as 'Robo-debt', etc." (Zalnieriute, Burton-Crawford, Boughey, \& Logan, 2020: 253). The fact that the majority of procedures are conducted under the administrative bodies also means a certain relation with public interests, as well as human rights and liberties, and therefore 
requires a higher degree of reliability. It is exactly those values that can be compromised with new technologies. The need to protect the basic rights and liberties states that the speed of the procedure is not the only and basic characteristic and principle of administrative procedure, but rather that it has to be observed in accordance with other values. That does not mean that the administrative procedure should not include the possibility of an automated decision making, but rather that with that type of decision making attention must be paid to the protection of parties and the public interest. Due to the aforementioned chanllenges in syn- cronising different interests, we come to the conclusion that automated decision making, at least in relation to the current state of information technologies, is not possible to apply in every administrative activity, because the automation of govermenet decision making has to follow the priciples of transparency, procedural fairness, reviewability, etc. (NG, O'Sullivan, Paters, \& Witzleb, 2020: 1042) Therefore, it poses a question which are the forms of administrative activities and decision making in the Republic of Serbia where automated decision making could be applied?

\section{SUITABILITY OF CERTAIN ADMINISTRATIVE ACTIVITIES FOR THE APPLICATION OF AUTOMATED DECISION MAKING}

The basic procedural law in the matter of administrative process is the Law of General Administrative Procedure (LGAP) (Milkov, 2016: 50) that determines the administrative activity as an individual situation in which a body, by directly applying laws, other regulations and general acts, legally and factually influences the position of the party by passing administrative acts, passing guarantee acts, concluding administrative contracts, undertaking administrative actions and providing public services (Tomić, Milovanović, \& Cucić, 2017: 23-24; Law on General Administrative Procedure - LGAP, Official Gazette of the Republic of Serbia, 18/2016, 95/2018). At first glance, it is clear that it is not possible to leave the decision making to computer programs in all of the mentioned forms of administrative work.

First of all, the current achievements in the area of computer science (informatics) allow the decision making based on the set parameters, while in practice, the implementation of such decisions made by the machines or programs is not at a high level. Specifically, robotics, within which the computer systems and programs are implemented in the hardware itself, or the functional machine, does not provide the possibility to conduct all the aforementioned activities of administrative bodies. Therefore, as part of the previously asked question, we can exclude the execution of administrative actions and providing public services from the domain of automatization. Also, when concluding administrative contracts, it is necessary to pay attention to private and public interests and therefore computer programs and artificial intelligence cannot represent one of the contracting parties in such a relation.

By the logic of things, the only administrative activities within which automated decision making can actually be applied are the enactment of adminis- 
trative and guarantee acts. Simple enactment of these acts is carried out based on relevant facts and established factual states to which the relevant laws and bylaws apply, and for which there is a basis to be conducted within the computer program.

However, we want to draw attention that this is only a factual aspect of decision making regarding administrative and guarantee acts using intelligent comput- er systems. This conclusion speaks only about the fact that the current state of information science and technology and administrative institutes enables decision making regarding certain forms of administrative activity. So, one question arises further. Is this possible from a legal point of view? More precisely, we ask the question whether the norms of general administrative procedure allow the automated decision making, especially in relation to administrative acts.

\section{GENERAL ADMINISTRATIVE PROCEDURE AND THE POSSIBILITY OF AUTOMATED DECISION MAKING}

The question of who makes decisions in the administrative procedure and in what way is regulated by the LGAP. Several provisions are relevant to our issue. First, reference should be made to the definition of the term 'administrative act'. An administrative act is an individual legal act by which the body, directly applying the regulations from the appropriate administrative area, decides on the right, obligation or legal interest of the party, or on procedural questions (LGAP: Article 16(1)). An important item, in relation to administrative work, is that the administrative act is issued by an administrative body. The administrative body, on the other hand, acts in an administrative matter through an authorized official. An authorized official is a person who has been assigned to a position that also includes the conduct of proceedings and decision making in administrative matters, or only the affairs of conducting proceedings or undertaking certain actions in the proceed- ings (LGAP: Article 39(1)). Regarding decision making, within the principle of truth and free assessment of evidence, it is stated that the authorized official decides (in administrative proceedings), according to his or her conviction which facts he or she takes as proven, based on conscientious and careful assessment of each piece of evidence separately and all evidence together, as well as based on the results of the entire procedure (LGAP: Article 10(2)).

As no norms can be found in other articles of the LGAP regarding the possibility of automated decision-making, we can conclude that such a form of decision-making is not allowed in the domestic general administrative procedure. This means that in the positive legislation, computer programs can be used only as an aid - a technical tool in creating and making a decision, but not for complete decision making in administrative proceedings. 


\section{IS THERE A POSSIBILITY FOR AUTOMATED DECISION MAKING IN ADMINISTRATIVE PROCEDURE?}

The development of information and communication technologies has had a significant impact on the observation of the form and manner of functioning of administrative bodies (Lilić \& Dimitrijević, 1998: 32). The influence of new technologies is so strong and widespread that today we talk about the existence of e-government (Kos, 2017: 84). The term e-government refers to the use of IT in order to increase the efficiency, economy and quality of public services, as well as transparency and accountability of administrative bodies (Koprić, Marčetić, Musa, \& Đulabić, 2014: 36). E-government has been one of the basic priorities of the Republic of Serbia in the last few years. For this purpose, the Strategy on the Development of E-Government in the Republic of Serbia for the Period 2015-2018 was adopted, as well as the Action Plan for the implementation of the strategy for the period 2015-2016, which refers to the manner of implementation of information technology in administrative procedures, as well as the operating environment of administrative bodies, so that the administration is transformed to a public service that will provide services and information to citizens in an efficient manner (Strategy on the Development of E-Government in the Republic of Serbia for the Period 2015-2018 and the Action Plan for the implementation of the Strategy for the period 2015-2016, Official Gazette of the Republic of Serbia, 107/2015).

In order to achieve the goals and plans from the Strategy, in 2018, the Law on Electronic Government was adopted, which regulates the performance of administrative bodies using information and communication technologies, as well as the prerequisites for the introduction of these technologies in the work of administrative bodies (Law on Electronic Government, Official Gazette of the Republic of Serbia, 27/2018). Despite the numerous technical and IT innovations it introduces, such as a single information and communication network of e-government, service network of administrative bodies, establishment and maintenance of registers and records in electronic form, a single electronic mailbox, e-government portal, etc. (Vučinić, 2020: 53), this law has not left room for the implementation of computer systems that could independently (automatically) make decisions in the administrative procedure. There are several reasons for that, and they range from the fact that computer programs are not at an adequate stage of development to be able to make decisions on their own, there are possibilities of malfunction and data compromising, the need to change the existing laws and other regulations based on which decisions can be made by the use of automated systems, violations of rights and liberties or public interest, etc. Despite the justification of the stated reasons, the authors of this paper believe that at this moment there is a possibility of freeing up space normatively for the implementation of computer systems that could automatically make some administrative decisions. Of course, firstly, we are of the opinion that automated decision-making should be about 'simple' decisions and questions that need to be made in large numbers in the first place, so therefore, there is a need to make their implementation in some way easier and faster, which would have a positive effect on the work of the administrative 
bodies, as they would have more available human resources at its disposal to perform other tasks.

When determining what the situations are in which it is possible to implement automated decision making, one should look at the types of decision making in administrative proceedings (Lončar, 2015: 179-195). Within the general administrative procedure, there is a possibility of direct decision making (without the examination procedure of the parties) and the decision making within the examination procedure. In the direct decision-making process, the administrative body can decide in four situations. The first one is when the factual situation can be established on the basis of facts and evidence presented in the request by the party itself or on the basis of generally known facts or facts known to the administrative body. The second one is if the factual situation can be determined on the basis of the data from official records and the party does not have to declare himself/herself in order to protect his rights and legal interests. The third one is if a verbal decision is made and the facts on which it is based are made plausible. The last one or the fourth situation is if it is determined by a special law (LGAP: Article 104(1)). In this type of decision making, the body makes the decision itself, without the party's statement and without conducting the examination procedure. Therefore, in the direct decision-making process, the administrative body decides in either of the following cases: when the factual situation is clear and the decision can be made 'easily'; when it is necessary to make a decision quickly having in mind the circumstances of the case, as is the case with oral decisions, or when the legislator considers it justified to be decided without conducting an examination procedure.

Authors believe that the possibility of automated decision making refers to the first two mentioned situations, within which the facts of the case allow the computer program to make the decision on its own, based on the data entered and the set parameters, without the need for an official (person) to supervise and participate in such proceedings. If the factual situation can be determined on the basis of evidence presented by the party or the facts collected from the official records (where there is no need for the declaration of the party), it is possible to enable digital and automatic making of such a decision. In such situations, it is necessary to create a digital form in which the party would enter the facts on their own or indicate which facts should be used, 'recalled', or downloaded from the official databases (an organized set of interconnected structured data, which may contain one or more records) which are stored in a digital form and which must be connected via the service network of the bodies (Law on Electronic Government: Article 4(1)). In this way, the potentials provided by the new information technologies and norms of the Law on Electronic Government would be used completely. 


\section{ASSUMPTIONS AND OBSTACLES TO AUTOMATED DECISION MAKING IN ADMINISTRATIVE PROCEDURE}

Having determined the situations that are suitable for accepting an automated decision-making system even at this moment of IT development, it is necessary to look at the required preconditions for the establishment of such a system. With each of the assumptions, a certain spectrum of problems arises, mostly of practical nature, to which it is necessary to pay appropriate attention.

The first assumption is of a technical nature and refers to the creation of a computer system itself, i.e. a program that would be able to make certain decisions. In addition to the technical element, it is necessary to establish a legal mechanism of action. Since the decision making would be automated, there would be an obligation to enable the exercise of rights to a legal remedy decided by an authorized official, in case the person affected by the automated decision is not satisfied with the outcome. In that way, the harmful consequences of irregularities in the work of digital technologies, i.e. the programs that originally decided, would be prevented.

Another important assumption to consider is the prevention of discriminatory decisions. Namely, in accordance with the Law on Electronic Government, everyone has the right to use the electronic government services and all users should have equal treatment, i.e. the manner and conditions for accessing the electronic government services (Law on Electronic Government: Article 7(1-2)). All users of services, i.e. parties must be treated in the same way, i.e. equally, which means that different decisions must not be made in the same factual case. Simply put, in an administrative procedure, both the public interest and the rights of citizens must be protected (Milkov, 2005: 247). We draw attention to the fact that the human factor is the one that is more likely to make different decisions about the same subjects rather than a computer program, whose algorithms are set in a way that the same results are always obtained, if the input parameters are identical.

Related to the previous assumption is the information security as well, which includes the protection of users' privacy, as well as their personal data, which are exposed to the dangers of new technologies (Mitrović, 2020: 87). This means that robust and reliable information security measures must be provided, such as security algorithms, accurately determining the circle and number of persons who have access to the submitted requests and databases in which the program stores the entered data and information related to the factual situation. Therefore, the rights related to the personal data protection, which are guaranteed by the Law on Personal Data Protection, must also be respected (Andonović \& Prlja, 2020: 87-115). This includes the right to information, the right to access personal data, the right to rectify and supplement personal data, the right to restrict the processing and the right to a legal remedy in relation with the processing of personal data.

In the context of the paper, it is especially interesting that the mentioned law envisages the rights related to the automated making of individual decisions. Namely, the data subject has the right not to be subjected to a decision made solely on the basis of automated 
processing, if that decision produces legal consequences for that person or if that decision significantly influences his or her position. The Law on Personal Data Protection accepts the possibility of making automated individual decisions (in relation to personal data), but approaches very carefully the possibility of applying those decisions, leaving the data subject (party in relation to the administrative bodies) to decide whether they accept such an automated type of decision (Law on Personal Data Protection, Official Gazette of the Republic of Serbia, 87/2018). However, a significant exception is made in relation to this right, in that the person will not decide whether the automated decision will be applied to him, if it is based on law, and that the law prescribes appropriate measures to protect rights, liberties and legitimate interests of the data subject (Law on Personal Data Protection: Article 38). If some other law introduced the possibility of automated decision making with the measures to protect private and public interests, the automated decision could be used even without the consent of the data subjects, i.e. parties. In that way, in the legal system of the Republic of Serbia, the idea of creating an automated decision making was opened for the first time, which should be monitored, developed, improved and finally applied in administrative norms and practice as well.

\section{CONCLUSION}

E-government represents a new stage in the development of states and a modern way of functioning of administrative bodies that use information and communication technologies in their work, as well as in their communication with parties, citizens and business entities. New technologies have encompassed almost all aspects of the work of administrative bodies. Having that in mind, the authors analysed the possibility of introducing new, digitally smart technologies within the decision-making process, i.e. decision making in the administrative procedure.

Currently the legal framework of the general administrative procedure in the Republic of Serbia does not allow the use of computer programs and information systems to make administrative decisions. Only an official person is authorized to analyse the facts of a specific case and to make a decision. However, due to the need for further implementation and greater use of new technologies in the work of administrative bodies, which is the general position of the government, as the holder of the entire executive power, the authors identified two cases in which, from practical and technical point of view, it could be allowed to use automated decision making. These are the situations in which a decision can be made in a direct decision-making procedure (without examination of parties), since the factual situation is established on the basis of facts and evidence presented by the party in the submitted request or on the basis of well-known facts or facts known to the body or, alternatively, if the factual situation can be determined on the basis of the data from the official records, and the party does not have to declare itself in order to protect its rights and legal interests. The two cases mentioned do not require a statement of the party and open the pos- 
sibility that, by creating a digital form for submitting requests and entering facts, the program makes a decision on its own, faster and more efficiently than it would be with a submission of a request and decision by an authorized person. Of course, in this situation, it is important to take into account the protection of human rights and liberties, primarily the right to privacy and the right to personal data protection, and allow the party the opportunity to appeal in case of dissatisfaction with the decision.

The development of society and social patterns of behaviour requires improve- ment and increase in efficiency of work of administrative bodies. Therefore, the scientific contribution of this paper lies in the aspiration to open new fields of theoretical and practical discussions on issues that have not been discussed much so far, and which will certainly arise in the near future. Therefore, for the development of administration, it is essential, as Kavran (2016: 149) states, that "we look for worthy answers and solutions for the future", a part of which is automated decision making in administrative procedure.

\section{REFERENCES}

Andonović, S. (2019). Zaštita podataka u elektronskoj javnoj upravi u Republici Srbiji - pravni aspekti (PhD thesis, University of Belgrade, Faculty of Law).

Andonović, S., \& Prlja, D. (2020). Osnovi prava zaštite podataka o ličnosti. Institut za uporedno pravo.

Bhosale, S., Salunkhe, A., \& Burondkar, M. (2020). A study of automated decision making systems. International Journal of Advance and Innovative Research, 7(1), 15-19.

Coglianese, C., \& Lehr, D. (2017). Regulating by robot: Administrative decision making in the machin-learning era. The Georgetown Law Journal, 105(6), 1147-1223.

Dimitrijević, P. (2009). Elektronska uprava i informaciono društvo. Moderna uprava - Časopis za upravno-pravnu teoriju i praksu, 121-134.

Jovanović, Z. (2016). Globalni trendovi u e-upravi i njihov uticaj na pružanje javnih usluga. In M. Mićović (Ed.), Usluge i uslužna pravila (pp. 683-700). Pravni fakultet Univerziteta u Kragujevcu.

Jovanović, Z. (2018). Aktuelni reformski procesi u javnoj upravi i globalizacija. Administracija i javne politike, 4(3), 33-50.

Kavran, D. (2016). Reforma javne uprave: misija i stvarnost. Pravni život, 3(11), 135-150.

Koprić, I., Marčetić, G., Musa, A., \& Đulabić, V. L.-N. (2014). Upravna znanost: Javna uprava u suvremenom europskom kontekstu. Pravni fakultet Sveučilišta u Zagrebu.

Kos, I. (2017). E-uprava. Pravnik: časopis za pravna i društvena pitanja, 51(102), 83-98.

Law on Electronic Government, Official Gazette of the Republic of Serbia, 27/2018. 
Law on General Administrative Procedure, Official Gazette of the Republic of Serbia, $18 / 2016,95 / 2018$.

Law on Personal Data Protection, Official Gazette of the Republic of Serbia, 87/2018.

Lilić, S., \& Dimitrijević, P. (1998). Informatička tehnologija i upravni akti. In N. Jauković, S. Stanković, \& S. Turajlić (Eds.), Zbornik radova sa III naučno-stručnog skupa Informacione tehnologije: sadašnjost i budućnost (pp. 36-38). Elektrotehnički fakultet Univerziteta Crne Gore.

Lončar, Z. (2015). Odlučivanje u upravnom postupku. Zbornik radova Pravnog fakulteta u Novom Sadu, 49(1), 179-195.

Milkov, D. (2005). Položaj stranke u upravnom postupku. Zbornik radova Pravnog fakulteta u Novom Sadu, 39(3), 241-253.

Milkov, D. (2016). Upravno pravo I: uvodna i organizaciona pitanja. Pravni fakultet Univerziteta u Novom Sadu.

Mitrović, L. (2020). Challenges risks and threats to human security on the 4th industrial revolution. NBP: Journal of Criminalistics and Law, 25(1), 81-98.

NG, Y.-F., O'Sullivan, M., Paters, M., \& Witzleb, N. (2020). Revitalising public law in a technological era: Rights, transaparency and administrative justice. University of New South Wales Law Journal, 43(3), 1041-1077.

Petrović, D. (2014). Društvena konstrukcija interpersonalnih medija: od telegrafa do interneta. In D. Todorović, D. Petrović, \& D. Prlja (Eds.), Internet i društvo (pp. 3-22). Srpsko sociološko društvo; Filozofski fakultet Univerziteta u Nišu; Institut za uporedno pravo.

Srđević, B., Srđević, Z., \& Suvočarev, K. (2007). Kompjuterski alati i sistemi za podršku odlučivanju u poljoprivredi. Letopis naučnih radova, 1(31), 55-64.

Tomić, Z., Milovanović, D., \& Cucić, V. (2017). Praktikum za primenu Zakona o opštem upravnom postupku. Ministarstvo državne uprave i lokalne samouprave.

UK's independent authority. (2019). What is automated individual decision-making and profiling? Retrieved September 25, 2020, from www.ico.org.uk: https://ico.org. $\mathrm{uk} /$ for-organisations/guide-to-data-protection/guide-to-the-general-data-protection-regulation-gdpr/automated-decision-making-and-profiling/what-is-automated-individual-decision-making-and-profiling.

Vučinić, D. (2020). Електронска управа: концепт и услуге са освртом на електронску управу у Републици Србији. Glasnik prava, 11(1), 45-56.

Welch, E., Hinnant, C., \& Moon, J. (2004). Linking citizen satisfaction with e-government and trust in government. Journal of Public Administration Research and Therory, 15(3), 371-391.

Zalnieriute, M., Burton-Crawford, L., Boughey, J. B.-M., \& Logan, S. (2020). From rule of law to statute drafting: Legal issues for algorithms in government decision-making. In W. Barfield (Ed.), Cambridge handbook on the law of algorithms (pp. 251-272). Cambridge University Press. 
